\title{
SKEMAMPUAN BERBAHASA PADA ANAK PENDERITA TUNAGRAHITA BERAT_STUDI KASUS: NURHUDA SURYA FININGSIH DI SLB NEGERI 1 PADANG
}

\author{
1. Anita Angraini Lubis; 2. Erna Ikawati \\ anitaangraini20@gmail.com
}

\begin{abstract}
Abstrak: Tujuan penelitian ini adalah untuk mendeskripsikan kemampuan berbahasa yang dapat dihasilkan oleh seorang anak penyandang disabilitas tunagrahita berat di SLB Negeri 1 Padang. Metode dan teknik yang digunakan dalam penelitian ini adalah, metode simak untuk tahap pengumpulan data dengan teknik sadap sebagai teknik dasar dan teknik lanjutan simak libat cakap (SLC), simak bebas libat cakap (SBLC), catat, dan rekam. Metode padan artikulatoris untuk tahap analisis data, dan metode penyajian formal dan informal untuk tahap penyajian hasil analisis data. Penelitian ini menemukan bahwa kemampuan produktif anak masih sangat minim dan butuh latihan yang keras serta waktu yang panjang agar dapat membuat sebuah perubahan dalam berbahasa untuk anak. Guru dan orangtua juga sebaiknya terus melatih anak dengan disiplin. Kemampuan menulis pada anak baru pada tahap menyambungkan titiktitik membentuk sebuah fonem. Cici belum bisa membuat satu fonempun dengan baik tanpa dibantu dengan titik-titik. Cici belum mampu membaca, berhitung, dan tidak suka menggambar. Kemudian, kemungkinan ada permasalahan saraf di otak anak yang menyebabkan tangan dan jari-jarinya selalu bergetar-getar. Keadaan emosinya sewaktu-waktu dapat memuncak dan tak terkendali.
\end{abstract}

Kata kunci: kemampuan berbahasa, tunagrahita berat.
Abstract: The purpose of this study was to describe the language skills that can be produced by a child with severe intellectual disability at SLB N 1 Padang. The method and technique used in this study were the referral method for the data collection stage with tapping techniques as basic techniques and advanced techniques of proficient involvement (SLC), proficient non-active listening (SBLC), notes, and records. Articulatory equivalent method for data analysis stage, and formal and informal presentation methods for the presentation phase of data analysis results. This study found that children's productive abilities are still very minimal and require rigorous training and long time so that they can make a change in language for children. Teachers and parents should also continue to train children with discipline. The ability to write to a new child at the stage of connecting the dots forms a phoneme. Cici hasn't been able to make one fonem well without being helped by dots. Cici hasn't been able to read, count, and doesn't like drawing. Then, there may be a nerve problem in the child's brain that causes his hands and fingers to always vibrate. His emotional state at any time can peak and uncontrollable.

Keywords: language skills, severe mental retardatio

\section{A. Pendahuluan}

Bahasa adalah alat komunikasi antara anggota masyarakat berupa simbol bunyi yang dihasilkan oleh alat ucap manusia. Berbahasa merupakan proses mengomunikasikan bahasa tersebut. Proses berbahasa 
sendiri memerlukan pikiran dan perasaan yang dilakukan oleh otak manusia untuk menghasilkan kata-kata atau kalimat. Artikulator yang baik akan mempermudah berbahasa dengan baik. Namun, mereka yang memiliki kelainan fungsi otak dan organ bicaranya, tentu mempunyai kesulitan dalam berbahasa, baik produktif maupun reseptif. Inilah yang disebut sebagai gangguan berbahasa.

Gangguan-gangguan berbahasa tersebut sebenarnya akan sangat mempengaruhi proses berkomunikasi dan berbahasa. Banyak faktor yang mempengaruhi dan menyebabkan adanya gangguan berbahasa, kemudian faktor-faktor tersebut akan menimbulkan gangguan berbahasa. Maka dari itu, dalam tulisan ini akan dijabarkan gangguan berbahasa yang sering dialami manusia berserta faktor-faktor yang menyebabkannya.

Untuk mampu berbahasa diperlukan kemampuan pemahaman (resepsi) dan kemampuan produksi (ekspresi). Implikasinya ialah daerah broca dan wernicke harus berfungsi penuh. Kerusakan pada kedua daerah tersebut dan sekitarnya akan menghasilkan gangguan berbahasa. Sementara, gangguan berbicara berhubungan dengan kesulitan menghasilkan bunyi yang spesifik untuk bicara atau dengan gangguan dalam kualitas suara.

\section{B. Kajian Teori}

Gangguan berbahasa ditandai dengan ketidakmampuan seseorang untuk berdialog interaktif, memahami pembicaraan orang lain, mengerti dan atau menggunakan kata-kata dalam konteks yang "nyambung" baik verbal maupun non verbal, menyelesaikan masalah, membaca dan mengerti apa yang dibaca, serta mengekspresikan pikirannya melalui kemampuan berbicara atau menyampaikannya lewat bahasa tulisan. Beberapa karakteristik dari gangguan berbahasa meliputi penggunaan kata yang tidak tepat, ketidakmampuan untuk menyampaikan pendapat, ketidaktepatan dalam penggunaan pola gramatikal, kosa kata yang 
minimal jumlahnya, dan ketidakmampuan untuk mengikuti instruksi. Mereka juga mengalami kesulitan dalam mengatur syntax.

Sementara, gangguan berbicara berhubungan dengan kesulitan menghasilkan bunyi yang spesifik untuk bicara atau dengan gangguan dalam kualitas suara. Ada yang disebut dysfluency atau stuttering (gagap), yaitu terjadi gangguan pada kelancaran berbicara, dan biasanya muncul di usia 3 atau 4 tahun. Gagap dapat hilang sendiri di usia remaja, namun tidak selalu demikian sehingga terapi wicara harus selalu dipertimbangkan. Gangguan bicara dapat juga berupa gangguan dalam artikulasi, hal ini disebut gangguan fonologi. Gangguan artikulasi adalah penggantian satu suara dengan suara lain, atau penghilangan satu suara, atau suara menjadi berubah sama sekali.

Selain itu juga dapat berupa gangguan dalam pitch, volume ataupun kualitas suara. Gangguan suara tipikal misalnya suara kasar, suara terputus-putus atau terengah-engah, suara yang terpecah jika dalam intonasi atau pitch yang tinggi. Gangguan suara seperti ini biasanya terjadi bersamaan dengan gangguan berbahasa lain sehingga disebut gangguan komunikasi kompleks.

Gangguan dalam berbahasa disebut afasia, dan afasia adalah si penderita gangguan berbahasa tersebut. Afasia terbagi atas dua bagian, yaitu afasia motorik dan afasia sensorik (Chaer 2003).

\section{Afasia Motorik}

\section{a. Afasia Motorik Kortikal}

Afasia ini merupakan kerusakan akibat hilangnya kemampuan untuk mengutarakan isi pikiran dengan menggunakan perkataan. Rusaknya korteks daerah broca yang merupakan tempat penyimpanan sandi-sandi perkataan merupakan titik kerusakan pada gangguan afasia jenis ini. Penderita dapat memahami bahasa lisan dan bahasa tulisan (ekspresi visual), namun tidak mampu memahami ekspresi verbal. 
b. Afasia Motorik Subkortikal

Afasia jenis ini merupakan gangguan berbahasa yang titik kerusakannya pada bagian bawah lapisan permukaan korteks atau disebut dengan subkortikal. Perkataan yang akan dikeluarkan masih tersimpan utuh di dalam korteks, namun perkataan itu tidak dapat dikeluarkan karena putusnya hubungan perintah ke otak. Penderitanya tidak dapat mengeluarkan isi pikirannya dengan menggunakan perkataan.

c. Afasia Motorik Transkortikal

Afasia jenis ini terjadi karena hubungan antara daerah broca dan wernicke terganggu. Pada umumnya gangguan afasia jenis ini merupakan lesikortika yang merusak sebagian daerah broca, jadi penderita mampu mengutarakan perkataan yang singkat dan tepat, tetapi masih mungkin menggunakan perkataan substitusinya.

\section{Afasia Sensorik}

Afasia sensorik disebabkan karena adanya kerusakan pada leksikortikal di daerah wernicke pada hemisferium yang dominan. Daerah ini terletak pada kawasan asosiatif antara daerah visual, sensorik, motorik, dan daerah pendengaran. Kerusakan pada daerah ini menyebabkan gangguan pada pengertian dan pendengaran, serta pengertian terhadap apa yang dilihat. Dengan kata lain, penderita akan kehilangan pengertian bahasa lisan dan bahasa tulis, walaupun penderita masih memiliki curah verbal yang tidak dapat dimengerti oleh dirinya sendiri.

\section{Jenis-Jenis Gangguan Berbicara}

Sastra (2011) menyatakan bahwa gangguan berbicara adalah salah satu bentuk kelainan perkembangan yang muncul dalam bentuk gangguan relasi (berinteraksi) dan komunikasi yang akhir-akhir ini terus meningkat. Untuk mengatasi gangguan berbicara ini, haruslah mewaspadai perkembangan anak sejak dini. 
Ada beberapa jenis-jenis gangguan berbicara menurut Morris dkk (2010) yang disebabkan oleh beberapa faktor diantaranya sebagai berikut.

\section{a. Gangguan Kefasihan.}

Biasanya penderita yang mengalami (fluency disorder) mengalami kegagapan, pengulangan kata-kata, latah atau memperpanjang bunyi, silaba atau kata tertentu. Gangguan kefasihan umumnya terjadi pada anak-anak. Misalnya menambahkan bunyi 'ooh', mengganti kalimat seperti papa pulang, kakak main. Mengulangi frasa seperti aku mau aku mau main atau mengulangi bunyi seperti a-a-a-aku mau makan. Seiring pertambahan usia dan semakin meningkatnya bahasa yang didapat dan siperoleh, gangguan kefasihan biasanya akan menghilang sendiri. tetapi ada juga yang tetap mengalami gangguan kegagapan hingga dewasa yang dapat menghambatnya dalam interaksi sosial.

Gagap biasanya diderita oleh anak-anak dan akan hilang seiring pertambahan usianya. Tetapi tidak sedikit orang dewasa yang mengalami kegagapan. Orang yang gagap sebenarnya tau bahwa tuturan yang dihasilkannya tidak benar tetapi dia tidak mampu dalam mengendalikan ujarannya. Selain gangguan komunikasi orang yang mengalami kegagapan juga dapat mengalami gangguan psikologis seperti minder dan enggan untuk begaul.

Para ilmuan menemukan bahwa $50 \%$ penderita gagap memiliki riwayat anggota keluarga yang mengalami kegagapan. Hal ini menunjukkan bahwa gagap merupakan gangguan yang dibawa sejak genetis. Para peneliti tersebut juga menemukan bahwa laki-laki lebih dominan mengalami kegagapan dari pada perempuan. Sebenarnya belum ada yang tau pati penyebab terjadinya kegagapan. Selain gagap, gangguan kefasihan juga dapat berupa gangguan psikogenetik seperti berbicara manja, berbicara kemayu dan latah. 


\section{Gangguan Artikulasi}

Artikulasi bunyi melibatkan organ bicara seperti lidah, gigi, bibir dan palatal. Gangguan artikulasi dapat diakibatkan oleh kangker mulut dan tenggorokan, kecelakaan dan bawaab lahir (seperti celah bibir). Atau factor lain yang mengakibatkan rusaknya organ bicara. Orang yang mengalami gangguan artikulasi biasanya bermaslah dalam melafalkan bunyi dengan keliru. Beberapa kesalahan artikulasi juga dipengaruhi oleh faktor bahasa ibu dan dialek daerah.

Gangguan artikulasi pada anak-anak masih dianggap normal, namun seiring perkembangannya, jika gangguan artikulasi masih terjadi maka hal tersebut sebagai kelainan atau penyakit. Selain faktor rusaknya organ wicara, factor neurologis juga dapat mengakibatkan gangguan artikulasi. Dishartria adalah gangguan motorik yang diakibatkan oleh lesi pada otak didaerah yang bertanggung jawabuntuk perencanaan eksekusi, dan pengendalian gerak otot yang dibutuhkan untuk bicara. Dysarthria biasanya ditemukan pada orang yang pernah mengalami stroke, tumor, dan penyakit degenerative seperti Parkinson. Orang yang mengalami Dysarthria mengalami serak dan parau, bahkan tidak dapat bicara samasekali. Penderita biasanya bicara pelan dan tidak jelas dan sulit dimengerti karena kesalahan artikulasi konsonan. indikasi lain Dysarthria biasanya penderita berbicara melalui hidung dan seperti bergumam. Namun demikian, gejala tergantung pada likasi dan kadar kerusakan sistem saraf.

Gangguan sistem syaraf yang dapat menimbulkan gangguan bicara adalah Apraxia atau dikenal dengan motorik-fonetik (Jack dan Robin), yaitu gangguan yang diakibatkan oleh kerusakan bagian otak yang berhubungan dengan proses bicara yang mengakibatkan ketidakmampuan yang menerjemahkan bentuk gramatikal kedalam 
susunan fonetik yang benar. Penderita biasanya mengalami kesulitan, susunan fonetis, irama dan waktu atau bicara sesuatu yang berbeda dari maksudnya.

Apraxia pada anak-anak (Developmental Apraxia Of Speech), ditandai dengan keterlambatan bicara. Anak-anak yang mengalami gangguan ini tidak melewati tahap babbling. Seiring bertambahnya usia, pada saat dewasa mereka mengalami kesulitan dalam mengucapkan frasa atau kalimat yang panjang. Anak yang mengalami masalah dengan kemampuan otaknya dalam pengolahan dan penyampaian sinyal yang dibutuhkannya untuk bicara. Diantara faktor yang menyebabkan keterlambatan bicara pada anak antara lain gangguan pendengaran, gangguan pada otot bicara, keterbatasan kemampuan kognitif, mengalami gangguan parvasiv, dan kurangnya komunikasi dan interaksi dengan orang tua dan lingkungannya (Sastra 2011)

Apraxia pada orang dewasa dapat disebabkan oleh stroke, tumor atau penyakit lain yang dapat mempengaruhi otak.

\section{Gangguan suara}

Gangguan suara meliputi gangguan nada, gangguan kualitas bunyi, dan gangguan kenyaringan. Gangguan suara biasanya dapat berupa kemonotonan nada, parau serak, bunyi yang terlalu rendah atau terlalu tinggi, atau kualitas bunyi nasal seseorang. Gangguan suara dapat diakibatkan oleh, kecelakaan, kerusakan atau penyakit pada tenggorokan dapat menyebabkan pita suara tidak bekerja dengan baik sehingga menyebabkan gangguan suara.

Spasmodic dysphonia merupakan gangguan suara disebabkan oleh kejangnya pita suara. Hal tersebut mengganggu aliran udara pada pita suara sehingga menghasilkan bunyi tersendat, gemetar, suara merintih. Kejang pada pita suara juga dapat mengakibatkan 
Aphonia (hilangnya suara), puberphonia (rentang suara yang sangat tinggi) dan dyshopia (penurunan kualitas suara).

\section{Apraxia}

Ganguan saraf lain yang dapat menimbulkan ganguan bicara adalah Apraxia atau dikenal dengan motorik-fonetik (Jack dan Robin, 2010), yaitu gangguan yang diakibatkan oleh kerusakan bagian otak yang berhubungan dengan proses bicara yang mengakibatkan ketidakmampuan menerjemahkan bentuk gramatikal kedalam susunan fonetik yang benar.Penderita biasanya mengalami kesulitan, susunan fonetis, irama dan waktu, atau berbicara sesuatu yang berbeda dari yang dimaksudkannya.

Apraxia pada anak-anak (Developmental Apraxia of Speech), ditandai dengan keterlambatan bicara. Anak-anak yang mengalami gangguan ini tidak melewati tahap babbling. Seiring bertambahnya usia, pada saat dewasa mereka mengalami kesulitan dalam mengucapkan frasa yang atau kalimat yang panjang. Anak yang mengalami masalah dengan kemampuan otaknya dalam pengolahan dan penyampaian sinyal yang dibutuhkan untuk berbicara. Diantara faktor yang menyebabkan keterlambatan bicara pada anak antara laian, gangguan pedengaran, gangguan pada otot bicara, keterbatasan kemampuan kognitif, mengalamai gangguan pervasive, dan kurangnya komunikasi dan interaksi dengan orang tua dan lingkungannya.

Apraxia pada orang dewasa (Acquire Apraxia) agak berbeda dengan Apraxia pada anak-anak karena mereka telah memiliki bahasa. Gangguan pada orang dewasa biasanya ditandai dengan ketidakmampuannya dalam menyusun kata atau silaba dengan benar. Mereka biasanya sadar akan kesalahannya dan berusaha mengulangi tuturannya dengan benar. 


\section{Tuna Grahita}

American asocoation on mental Deficiency / AAMD dalam BP3PTKSM, (p. 20) mendefinisikannTunagrahita sebagai kelainan :

a. Meliputi fungsi intelektual umum di bawah rata-rata (sub-average), yaitu IQ 84 ke bawah berdasarkan tes; Muncul sebelum usia 16 tahun

b. Menujukan hambatan dalam perilaku adaptif.

Sedangkan pengertian tunagrahita menurut Japan League for Mentally Retarded (1992:p.22) dalam B3PTKSM (p. 20-22) sebagai berikut.

a. Fungsi intelektualnya lamban, yaitu IQ 70 kebawah berdasarkan tes intelegensi baku

b. Kekurangan dalam prilaku adatif

c. Terjadi pada masa perkembangan, yaitu antara masa konsepsi hingga usia 18 tahun

Pengklasifikasian / penggolongan anak tunagrahita untuk keperluan pembelajaran menurut America Association on Mental Retardation dalam Spesial Education in Ontario Schools (p. 100) sebagai berikut.

a. Educable

Anak pada kelompok ini masih mempunyai kemmapuan dalam akademik setara dengan anak reuler pada kelas 5 sekolah dasar.

b. Trainable

Mempunyai kemampuan dalam mengurus diri sendiri, pertahanan diri, dan penyesuaian sosial. Sangat terbatas kemapuan untuk pendidikan secara akademik.

c. Custodial

Dengan pemberian latihan yang terus menerus dan khusus, dapat melatih anak tentang dasar-dasar cara menolong diri sendiri 
dan kemampuan yang bersifat komunikatif. Hal ini biasanya memerlukan pengawasan dan dukungan terus menerus. Sedangkan penggolongan tunagrahita untuk keperluan pembelajaran menururt B3PTKSM (P.26) sebagai berikut.

1) Taraf perbatasan (border line) dalam [pendidikan disebut sebagai lamban belajar (slow learner) dengan IQ $70-85$

2) Tunagrahita mampu didik (educable mentally retarded) dengan IQ $50-75$

3) Tunagrahita mampu latih (dependent of proudlley retarded dengan Q 30 - 50 atau IQ 3 -55

4) Tunagrahita butuh rawat ( dependent of proudlly mentally retarded dengan IQ $25-30$.

Pengolongan tunagrahita secara medis - biologis menurut Roan, 1979 dalam B3 PTKSM sebagai berikut.
a. Retardasi mental taraf perbatasan (IQ 68 - 85)
b. Retardasi mental ringan (IQ 52 - 67)
c. Retardasi mental sedang (IQ 36 - 51)
d. Retardasi mental berat ( 20 -35)
e. Retardasi sangat berat (IQ $<20$ dan
f. Retadasi mental tak tergolongkan.

Adapun penggolongan tunagrahita secara Sosial psikologis terbagi 2 kriteria, yaitu: Psikometrik danprilaku adaptif. Ada 4 taraf tunagrahIta berdasarkan kriteria psikometrik menurut skala intelegensi Wechler ( Kirk angallaghrr, 1979, dalam B3PTKSM, p. 26) yaitu :
a. Retardasi mental ringan (mild mental retardation dengan IQ 55 - 69)
b. Retardasi mental sedang ( moderat e mental reterdation dengan IQ 40 -54 )
c. Retardasi mental berat (sever mental retardation dengan IQ 20 - 39)
d. Etardasi mental sangat berat (provan mental retardation IQ <20) 


\section{Metode}

Metode dan teknik yang digunakan dalam penelitian ini adalah, metode simak untuk tahap pengumpulan data dengan teknik sadap sebagai teknik dasar dan teknik lanjutan simak libat cakap (SLC), simak bebas libat cakap (SBLC), catat, dan rekam. Metode padan artikulatoris untuk tahap analisis data, dan metode penyajian fornal dan informal untuk tahap penyajian hasil analisis data. Tata cara aplikasi metode dan teknik yang digunakan pada penelitian ini adalah dengan fokus mengamati satu subjek penelitian. Setiap mahasiswa memasuki kategori kelas yang terdiri atas kelas A, B, C, dan C1. Kemudian, mengamati kemampuan anak-anak tersebut, setelah itu menetapkan satu subjek penelitian yang dirasa cocok. Teknik yang dilakukan, mengajak mereka berinteraksi, memperhatikan selama proses belajar mengajar dengan gurunya, ikut membuat kerajinan tangan bersama mereka, mengajak mengobrol, bernyanyi, menggambar, mendegarkan mereka membaca. Setelah itu merekam pembicaraan selama proses tersebut sedang berlangsung. Memberikan pancingan dan stimulus agar si anak merespon atau tidak masukan tersebut.

\section{Hasil dan Pembahasan}

\section{Temuan Umum Kasus dan Data Subjek}

Dalam pengamatan yang dilakukan, diambil satu orang subjek penelitian dari kelas C1 dengan kategori tunagrahita berat. Kemudian, permasalahan saraf di otak anak yang menyebabkan tangan dan jarijarinya selalu bergetar-getar. Keadaan emosinya sewaktu-waktu dapat memuncak dan tak terkendali. Identitas ini langsung diterima dari pihak sekolah.

$\begin{array}{ll}\text { Nama Siswa } & \text { : Nurhuda Surya Finingsih } \\ \text { Jenis Kelamin } & : \text { Perempuan } \\ \text { Kategori Kelas } & : \text { Kelas C1 }\end{array}$


Tempat/Tanggal Lahir : Padang/ 23 Juli 2003

Agama

Ayah

Ibu

Jumlah Saudara

Alamat

Penggunaan Bahasa
: Islam

:Yusrizal

: Julita

: 3 orang

: Tanjung Saba, Pitameh RT 03 RW 04

No.26

: Minang

\section{Jenis Gangguan Bahasa yang Teramati}

Pada subjek penelitian yang diambil ini, gangguan bahasa pada anak sangat kompleks. Usia anak sudah menginjak 13 tahun tetapi kemampuan bahasa yang dimilikinya juga masih sangat jauh dibawah rata-rata. Penguasaan kosa kata masih cukup minim, dapat dikategorikan seperti usia anak yang masih 5 tahun. Pemikirannya juga mengalami ketidakseimbangan, ketika ditanyakan sesuatu si anak yang akrab disapa Cici ini menjawab pertanyaan sesuai dengan yang diinginkan walaupun sebelum menjawab ada jeda untuk berpikir beberapa menit terlebih dahulu. Bahasa yang digunakan si anak untuk berkomunikasi sehari-hari adalah bahasa Minang. Ketika si anak tidak dituruti keinginannya maka yang terjadi adalah sewaktu-waktu emosi anak akan meledak tak terkendali. Dia akan memukul dan melemparkan suatu benda yang ada dekat dengan dirinya. jari dan tangannya tidak akan berhenti bergetar. Si anak juga sewaktu-waktu dapat berteriak cukup keras jika suatu hal yang dia inginkan tidak diberikan saat itu juga padanya.

Anak belum mampu membaca sama sekali dan cukup sulit untuk mengajarkannya. pada kemampuan menulis anak hanya 
mampu menyambungkan titik-titik, kemudian mengikuti titik-titik tersebut membentuknya menjadi sebuah fonem. Ketika kita menyebutkan nama, walaupun sudah kita ulang hampir sepuluh kali pengulangan, si anak baru mampu mengucapkannya kembali, tetapi ketika kita menanyakan kembali dalam jeda waktu yang tidak terlalu panjang, dia akan lupa kembali siapa nama kita. Anak pada taraf dengan gangguan seperti anak hanya mengingat nama saudara atau orang-orang yang sudah sangat dekat dan tinggal bersamanya dalam waktu yang lama.

\section{Kemampuan Verbal Cici:}

\begin{tabular}{|c|c|c|}
\hline No. & Kata & Ujaran Cici \\
\hline 1. & Minum & [num] \\
\hline 2. & Dua & {$\left[\mathbf{u}^{\mathbf{w}} \mathbf{a}\right]$} \\
\hline 3. & Empat & [epat] \\
\hline 4. & Ayok & [jo?] \\
\hline 5. & Apa itu & [a to] \\
\hline 6. & Tidak & [da?] \\
\hline
\end{tabular}

Kemampuan fonologis anak masih sangat minim sekali. Cici mampu mengujarkan kata-kata, sampai kalimat yang panjang pun dapat diujarkan, tetapi bunyi-bunyi yang keluar dari alat ucapnya tidak jelas. Oleh karena itu, kemampuan verbal anak masih sangat terbatas dan harus banyak latihan dan terapi-terapi yang dilakukan agar kebahasaan si anak mengalami kemajuan yang lebih pesat, dan anak lebih dapat hidup mandiri ke depannya. 


\section{Jenis Gangguan Berbicara yang Teramati}

Anak mengalami apraxia sesuai dengan pengamatan peneliti, tetapi hal ini juga belum dapat dipastikan secara klinis. Menurut penuturan guru pembimbing yang berada di sekolah, belum ada pemeriksaan ke dokter yang dilakukan oleh orangtua si anak, jadi pihak sekolah tidak mengetahui dengan jelas secara medis penyakit apa yang diderita oleh anak. Ganguan saraf seperti ini menimbulkan ganguan bicara. Apraxia atau dikenal dengan motorik-fonetik, yaitu gangguan yang diakibatkan oleh kerusakan bagian otak yang berhubungan dengan proses bicara yang mengakibatkan ketidakmampuan menerjemahkan bentuk gramatikal ke dalam susunan fonetik yang benar. Penderita biasanya mengalami kesulitan, susunan fonetis, irama dan waktu, atau berbicara sesuatu yang berbeda dari yang dimaksudkannya.

Ketika ditanyakan perhitungan sederhana, anak tidak mampu menjawab dan ketidak seimbangan antara artikulator anak ketika mengucapkan dengan motoriknya. Peneliti menanyakan $2+2$ itu sama dengan berapa. Dia menjawab 2 dan membuat jarinya 4. Selain permasalah saraf, artikulator anak juga mengalami gangguan, intonasi yang sangat keras setiap kali berbicara. Kata-kata yang keluar sama sekali tidak jelas termasuk bentuk sintaksis apa yang ingin ia tuturkan, hanya fonem-fonem vokal yang jelas dari yang dia ujarkan.

\section{Kemampuan Reseptif Subjek}

Kemampuan reseptif anak terkait kemampuannya dalam menanggapi rangsang, input, atau masukan yang datang dari luar diri atau dari lingkungannya. Tidak ada masalah dengan kemampuan reseptif anak. Cici mampu memahami setiap pertanyaan yang diajukan padanya, tetapi membutuhkan jeda waktu untuk memikirkan 
pertanyaan tersebut sebelum menjawabnya. Sementara, ketika proses belajar mengajar berlangsung, hal yang dilakukan oleh gurunya adalah melalui visualisasi atau media gambar. Misalnya untuk menyebutkan 'daun', maka bentuk benda tersebut harus diperkenalkan. Daun itu seperti apa, bentuk dan warnanya bagaimana, serta perlahan mengajarkan mengucapkan bentuk kata 'daun' itu sampai mampu diucapkan oleh anak, Pernah ada satu kejadian, si anak mampu mengucapkan kata 'batang', tetapi tidak mengetahui 'batang' itu apa, dan bentuknya seperti apa.

Cici ketika disuruh untuk makan dengan baik, dia mengerti. Ketika guru melihat mejanya basah dan dia mengambil kain lap untuk mengeringkan meja tersebut. Hal ini menunjukkan tidak ada permasalah reseptif yang kompleks pada si anak, dikarenakan dia memahami perintah dan pertanyaan yang ditujukan padanya.

\section{Kemampuan Produktif Subjek}

Kemampuan produktif anak masih sangat minim dan butuh latihan yang keras, waktu yang panjang agar dapat membuat sebuah perubahan untuk anak. Guru dan orangtua juga sebaiknya terus melatih anak dengan disipilin. Kemampuan menulis pada anak baru pada tahap menyambungkan titik-titik membentuk sebuah fonem. Cici belum bisa membuat satu fonempun dengan baik tanpa dibantu dengan titik-titik. Cici belum mampu membaca, berhitung, dan tidak suka menggambar. Hal ini cukup menyulitkan tenaga pengajar di sekolah untuk melatih saraf motoriknya. Cici hanya mau belajr sesuai dengan kehendaknya, jadi gurulah yang dituntut untuk pandai-pandai menarik perhatiannya agar mau belajar dan menulis dengan tenang dan baik duduk di kursinya. 


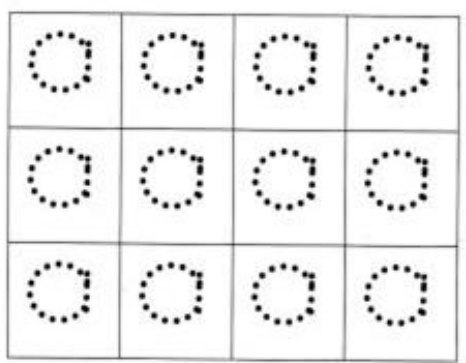

Gambar 1. Bantuan titik-titik untuk menulis dan membentuk fonem /a/

\section{Data Psikis dan Data Fisik Subjek}

Pihak sekolah tidak memiliki data tertulis dari kedua subjek. Pengamat memperoleh data psikis dan fisik subjek dengan cara menanyakan kepada guru kelas dan mengamati secara langsung kondisi psikis dan fisik subjek dari kedua subjek tersebut. Pengamat menyimpulkan sebagai berikut.

Secara fisik cukup terlihat kekurangan yang dialami anak. Mata anak tidak fokus melihat sesuatu, karena arah mata yang tidak normal tidak tepat berada di tengah. Tangan dan jari yang selau bergetar dan menegang tidak lentur dan tidak terkoordinasi dengan baik. Cici juga berjalan menyeret kakinya dengan cepat-cepat dan selalu tergesagesa, tidak mau diam di tempat. Anak yang sangat hiperaktif. Suara ketika berbicara juga keras dan sering menjerit tidak ada penyebabnya, atau karena hal yang diinginkannya terkadang tidak diberikan.

Secara psikis si anak cenderung asik dengan dirinya sendiri, terkadang berbicara sendiri. Tidak menghiraukan orang lain. Ketika bermain dengan temannya dia tidak segan-segan untuk menariknya. Bahkan orang yang pertama kali dia kenal, Cici sama sekali tidak malu untuk menarik dan meminta foto dan mengambil paksa benda yang menurutnya ingin dimilikinya. Anak ini menjadi tak terkendali ketika 
guru memarahinya karena tidak mau duduk di kursi dan menumpahkan air minum, kemudian dia menunduk cukup lama dan menendang-nendang meja menunjukkan kemarahannya dan tingkat emosi yang tidak terkendali dari anak ini.

\section{Interaksi Sosial Subjek}

Cici berinteraksi dengan orang lain cukup cepat. Ketika peneliti menanyakan namanya, alamat rumahnya dia langsung menjawab walaupun sama sekali tidak jelas dan tidak mendengar dengan baik apa yang dia ucapkan. Kemudian, dia menarik tangan untuk berfotofoto, dan mengambil telopon genggam peneliti untuk melihat hasil fotonya. Dia juga meminta untuk berfoto satu per satu dengan temanteman penliti lainnya, kemudia dia berfose agar terlihat lucu di dalam kamera.

Interaksi dengan teman-teman lainnya sama sekali tidak ada kendala, Cici bukan anak yang pemalu. Dia mengajak dan memanggil temannya dengan sangat keras agar ikut berfoto bersama dengan dirinya, ketika temannya tidak mau maka dia akan memaksa dengan menarik tangannya sampai temannya menuruti keinginannya. Jika temannya tetap tidak mau, dia akan menjerit dan pergi meninggalkan temannya tersebut sembari menolak badan temannya.

Kendala emosi yang meledak-ledak yang dialami oleh cici, menjadi penyebab sulitnya ia berinteraksi dengan teman atau orang baru yang baru mengenalnya, guru yang sudah 5btahun terakhir membimbingnya juga cukup kewalahan. Beliau mengatakan, tahun pertama ketika Cici di sekolah ibunya selalu mengawasi dan tidak pernah meninggalkan Cici di sekolah karena tingkat emosi dan pikirannya yang tidak stabil, dikhawatirkan dapat membahayakan orang lain. Akan tetapi, setahun terakhir ini, emosinya sudah mulai dapat diatur dan sudah mulai dapat tenang jika dimarahi oleh gurunya. 


\section{E. Simpulan}

Masa usia dini merupakan periode emas bagi perkembangan anak untuk memperoleh proses pendidikan. Periode ini adalah tahun-tahun berharga bagi seorang anak untuk mengenali berbagai macam fakta di lingkungannya sebagai stimulansi terhadap perkembangan kepribadian, psikomotor, kognitif maupun sosialnya. Dalam pengamatan yang dilakukan, diambil satu orang subjek penelitian dari kelas C1 dengan kategori tunagrahita berat. Kemudian, permasalahan saraf di otak anak yang menyebabkan tangan dan jari-jarinya selalu bergetar-getar. Keadaan emosinya sewaktu-waktu dapat memuncak dan tak terkendali.

Kemampuan produktif anak masih sangat minim dan butuh latihan yang keras, waktu yang panjang agar dapat membuat sebuah perubahan untuk anak. Guru dan orangtua juga sebaiknya terus melatih anak dengan disipilin. Kemampuan menulis pada anak baru pada tahap menyambungkan titik-titik membentuk sebuah fonem. Cici belum bisa membuat satu fonempun dengan baik tanpa dibantu dengan titik-titik. Cici belum mampu membaca, berhitung, dan tidak suka menggambar.

Pada subjek penelitian yang diambil ini, gangguan bahasa pada anak sangat kompleks. Usia anak sudah menginjak 13 tahun tetapi kemampuan bahasa yang dimilikinya juga masih sangat jauh di bawah rata-rata. Penguasaan kosa kata masih cukup minim, dapat dikategorikan seperti usia anak yang masih 5 tahun. Pemikirannya juga mengalami ketidakseimbangan, ketika ditanyakan sesuatu si anak yang akrab disapa Cici ini menjawab pertanyaan sesuai dengan yang diinginkan walaupun sebelum menjawab ada jeda untuk berpikir beberapa menit terlebih dahulu. Bahasa yang digunakan si anak untuk berkomunikasi sehari-hari adalah bahasa Minang. Ketika si anak tidak dituruti keinginannya maka yangv terjadi adalah sewaktu-waktu emosi anak akan meledak tak terkendali. Dia akan memukul dan melemparkan suatu benda yang ada dekat dengan dirinya. jari dan tangannya tidak akan berhenti bergetar. Si 
Jurnal kajian gender dan anak

Vol. 02 No. 1 Juni 2018

Pusat Studi Gender dan Anak

IAIN Padangsidimpuan

anak juga sewaktu-waktu dapat berteriak cukup keras jika suatu hal yang dia inginkan tidak diberikan saat itu juga padanya. Sehingga diharapkan kerja sama yang baik antara orangtua, kelauarga, tenaga pendidik, psikotertapis, speech therapist, serta dokter untuk penaganan yang lebih maksimal ke depannya terhadap Cici. 


\section{REFERENSI}

Chaer, Abdul. 2003. Psikolinguistik: Kajian Teoritik. Jakarta: PT Rineka Cipta.

Dachrud,Musdalifah.JURNAL PSIKOLOGI VOLUME 37, NO. 1, JUNI 2010."Studi Meta analisis Terhadap Intensitas Terapi Pada Pemulihan Bahasa Afasia.

Firman. "Orientasi Model Pembelajaran Bahasa Indonesia." JURNAL PRIMARY. Vol.04 No. 02. Juli - Desember 2012.

Sastra, Gusdi. 2011. Neurolinguistik Suatu Pengantar. Bandung: Alfabet.

Jacks, Adam dan Donald A. Robin. 2010. "Apraxia of Speech" dalam The Handbook of Language and Speech Disorders, ed. Jack S. Damico, Nicole Müller, dan Martin J. Ball, 391-409. Blackwell: United Kingdom.

Morris, Richard dan Archie Bernard Harmon. 2010. Describing Voice Disorders dalam The Handbook of Language and Speech Disorders, ed. Jack S. Damico, Nicole Müler, dan Martin J. Ball, 454-473. Blackwell, United kingkom. 